\title{
My path to The Calculus of Consent
}

\author{
Gordon Tullock
}

(c) Springer Science+Business Media, LLC 2012

Upon earning a J.D. from the University of Chicago Law School and passing the Foreign Service examination in 1947, I joined the U.S. State Department's Foreign Service. My first assignment was as vice-consul in Tientsin, China. Since few foreigners lived in or visited Tientsin in 1948-1949 and Chinese citizens were reluctant to be seen with Americans, my official duties were light. We were quite nervous upon the arrival in Tientsin of the Communists in January 1949, but in fact they mostly ignored the US Consulate there and the State Department wanted us to stay. For nearly a year I continued to live in my apartment with my cooks and servants. Eventually, as the last of the remaining consulate staff, I packed my bags, went to the docks and boarded an English coastal vessel destined for Hong Kong.

My interest in economic systems was awakened by those days in China. Up to that time my formal training in economics consisted of one graduate course taught by Henry Simons in the law school. The contrasts of living in the United States, in China under the Nationalists and then under the Communists had a great influence on my future thinking and research. My respect for American-style capitalism grew.

Following nearly seven more years of rather dull Foreign Service assignments, I resigned my government position in 1956. For the next two years I was mostly engaged in writing.

It was my great good fortune to be awarded a Post Doctoral Fellowship at the Thomas Jefferson Center for Political Economy of the University of Virginia for the 1958-1959 academic year. The result was the beginning of fruitful collaboration with James Buchanan, who was already a well-established scholar. The initial product of that collaboration was The Calculus of Consent. For some of the details of how this book was conceived and executed, one is advised to consult the book's preface.

G. Tullock (凶)

George Mason University School of Law, 3301 Fairfax Drive, Arlington, VA 22201, USA

e-mail: gtulloc1@gmu.edu 